\title{
フィラー分散が成形加工性に及ぼす効果
}

隠 塚 裕 之

\section{Influence of Filler Dispersion on Processability of Rubber}

Hiroyuki ONTSUKA (Chemicals Evaluation and Research Institute, Nagoya, Japan, 1, 4-Chome, Orito-cho, Showa-ku, Nagoya-shi, Aichi 466-0858, Japan)

Dispersion of filler such as carbon black into the rubber greatly affects the durability of the rubber products. The necessity of determination of the filler dispersion, especially, has been frequently discussed. On the other hand, in comparison with the evaluation method of the vulcanized rubber for the CB dispersion, evaluation methods of the unvulcanized rubber is very limited.

The evaluation methods of the filler dispersibility are prescribed in standards of ISO and ASTM, but standards of JIS does not include them. In this paper, I comment on test methods about the processability of unvulcanized rubber and describe the influence of filler dispersion on rubber processability.

(Received on January 15, 2016)

Key Words : Processability, Rubber Mixing Process, Filler Dispersion, Carbon Black Dispersion, Mooney Stress Relaxation, Mooney Viscosity, Green Strength, Garvey Die, Plasticity

\section{1. は じ め に}

ゴム製品は，複数の加工工程を経て製造されおり，その 一つ一つの工程が，製品性能やコストに重大な影響を及ぼ す.この加工工程のなかで, シリカやカーボンブラック （CB）に代表されるフィラーの分散状態が加硫ゴムの強度 や耐摩耗性に大きく寄与し, 製品性能に大きく影響を与え ることが知られている.フィラー分散が加硫ゴムの物理特 性に及ぼす影響については多くの論文があり，CBの分散 状態が疲労特性に影響を与えるとの報告 ${ }^{1)}$ 等や, $\mathrm{CB}$ の分 散機構に関する藤本ら ${ }^{2,3)}$ の議論，および，近年の阿波根 $ら^{4)}$ によるCB分散機構の提案が注目される.

また，ゴム製品の性能評価は，製品や材料に応じて多岐 にわたって行われ，その評価方法はJIS（Japanese Industrial Standard), ISO (International Organization for Standardization), ASTM (American Society for Testing and Materials) 等の物理試験方法が引用されている. 一方, その製品を製造する際の品質を担う加工工程での原 料ゴム, 練りゴムを対象とした未加硫ゴムの加工性評価に ついては, 規格や各社スペックが少なく, 評価方法も限ら
れているのが現状である。ちなみに, ISO/TC45/SC2物 理試験分科会が扱う規格においても，110件以上あるISO の中で, 未加硫ゴム試験は 10 件程度である.JISにおいて は, 更に少ない 5 件程度しか規格化されておらず, 今後の, 加工性評価の規格の拡充が期待される.

このように，フィラー分散性と加硫ゴム物性については 多くの報告があるが，フィラー分散性と成形加工性につい ての報告はほとんど無いのが現状である。ここでは, 未加 硫ゴムの加工性評価について, 規格に規定される試験方法 を解説し, その中で, フィラーの分散が成形加工性に与え る影響評価について述べる. 


\section{2. 各種規格における加工性評価}

\section{1 試料作製方法}

原料ゴムからゴムコンパウンドを経て加硫ゴム試料を作 製する際の規格は，JIS K 6299：2012「ゴム－試験用試料 の作製方法」 ${ }^{5)}$ 及びISO 2393：2014「Rubber test mixes

- Preparation, mixing and vulcanization - Equipment and procedures」 ${ }^{6)}$ がある.ここでは, 配合剤の準備, 混 練機 (種類・サイズ・練り量), 混練り手順, 加硫の前成形, 加硫操作 (加硫プレス, 金型)，標準配合等が規定されてお り，試験用試料を作製する際の標準的な手順が網羅されてい る.

また，附属書として，この標準配合を用い規定の手順で 試料作製を行い，試験室内比較や試験室間比較を行う方法 及びラウンドロビンテストの結果が記載してある。結果の 統計的なデー夕処理方法なども記載されており，社内の標 準化やラボ間の比較に利用すると便利である.

\section{2 粘度（可塑度）}

未加硫ゴムの評価において，もっとも汎用的に使用され ているのが粘度（可塑度）であろう。実際に粘度（可塑 度）は，製造工程に大きな影響を及ぼすことが知られてお り，加工性評価として種々の試験方法が規定されている. 表 1 に主な粘度（可塑度）の測定装置・規格を示す.

ゴム工業においては，JIS K 6300-1：2013「未加硫ゴム 一物理特性一第 1 部：ムーニー粘度計による粘度及びスコ 一チタイムの求め方」 ${ }^{7)}$, ISO 289-1：2015, 「Rubber, unvulcanized - Determinations using a shearing-disc viscometer - Part 1 : Determination of Mooney viscosity $\rfloor^{8)}$ 及びASTM D 1646-07「Standard Test Methods for RubberViscosity, Stress Relaxation, and Pre-Vulcanization Characteristics (Mooney Viscometer)」 ${ }^{9)}$ に規定されるムーニ 一粘度が一般的で，標準条件 $\left(100^{\circ} \mathrm{C} ， 1\right.$ 分予熱，4分後 で測定した測定值（ML1+4100 ${ }^{\circ} \mathrm{C} ）$ は世界共通でデータ が認識可能である。しかし近年では，原料ポリマーの多様 化（高粘度，高分子量など）により，ゴムとローターとの スリップや測定限界オーバーのような，ムーニー粘度計で
測定が困難なケースが散見される。そこで，高粘度ポリマ 一の粘度測定のために，ムーニー粘度計に代わる他の手法 で評価する試みがなされている，装置としては，ローター レスレオメータを用い, ねじりモードで粘弾性を測定し, ムーニー粘度の代替となるパラメーターを検討中である. 相関性が高い結果が得られた場合は, JIS化を視野に入れ て検討している。

\section{3 粘着性}

公定法としての試験方法は規定されていないが, タイヤ やホースなどのように異種のゴム材料や補強用の繊維等が 複合して使われる場合の作業性を評価するため, 又は，コ ンパウンドを保管する際の粘着性を把握する為に測定す る. 装置としてはピックアップ式タックメーター等を使用 して未加硫ゴムどうしを貼り合わせ，引き剥がす力を測定 する。使用する練り生地の作製条件，圧着力，保持時間な ど影響因子が多いので注意が必要である。

\section{4 押出性}

ホースやウエザーストリップなどの押出成形で作製され るゴム材の評価に用いる。押出機に特定の形状の口金を装 着し, 押出速度を可変して押出物の形状 - 寸法などより加 工特性を評価する. ASTM D 2230-96「Standard Test Method for Rubber Property-Extrudability of Unvulcanized Compounds」10) には図1に示すガーベイダイを用い る方法が規定されており, 膨張・気泡・ $30^{\circ}$ エッジの連続 性, 鋭さ・表面の肌荒れの状態などを観察し, 採点基準写

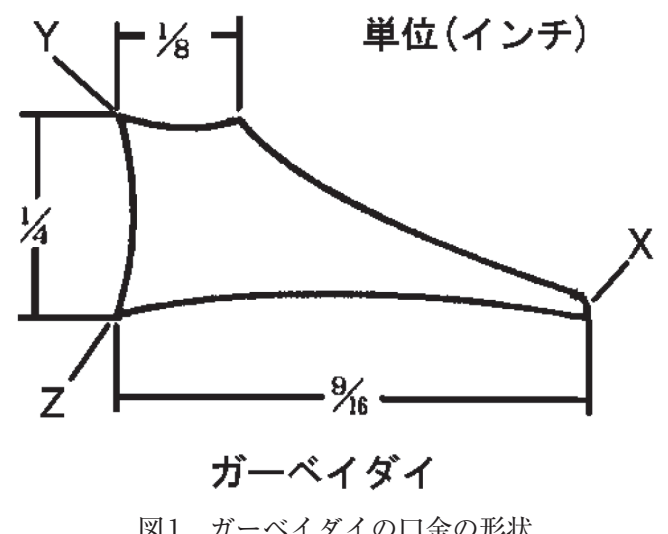

図 1 ガーベイダイの口金の形状

表 1 主な粘度（可塑度）の測定方法

\begin{tabular}{|c|c|c|}
\hline 種類 & 試験機 & 概要 \\
\hline \multirow[t]{2}{*}{ 平行板荷重式 } & $\begin{array}{l}\text { ラピッドプラストメーター } \\
\text { (JIS K 6300-3, ISO 2007, ASTM D 926) }\end{array}$ & \multirow[t]{2}{*}{$\begin{array}{l}2 \text { 枚の平行板の間に試験片を挟み, 2段階で荷 } \\
\text { 重を負荷しその変位量より可塑度を算出する }\end{array}$} \\
\hline & $\begin{array}{l}\text { ウイリアムス式 } \\
\text { (JIS K 6429, ISO 7323, ASTM D 6049) }\end{array}$ & \\
\hline 回転型 & $\begin{array}{l}\text { ムーニー粘度計 } \\
\text { (JIS K 6300-1， ISO 289-1， ASTM D 1646) }\end{array}$ & $\begin{array}{l}\text { ゴムで充填されたダイ中のローターを回転させ } \\
\text { たときに生じるトルクを測定し, 粘度を算出す } \\
\text { る }\end{array}$ \\
\hline \multirow[t]{3}{*}{ 押出型 } & $\begin{array}{l}\text { 押出機 } \\
\text { (ASTM D 2230) }\end{array}$ & $\begin{array}{l}\text { ガーベイダイより押出されたゴムの形状・外観 } \\
\text { を評価する }\end{array}$ \\
\hline & $\begin{array}{l}\text { フローテスター } \\
\text { (JIS K 7210, ASTM D 926) }\end{array}$ & \multirow[t]{2}{*}{$\begin{array}{l}\text { ピストンを一定荷重又は速度で押した時の応力 } \\
\text { /吐出量／速度を測定し, 粘度を算出する }\end{array}$} \\
\hline & $\begin{array}{l}\text { キャピラリーレオメーター } \\
\text { (JIS K 7199, ASTM D 5099) }\end{array}$ & \\
\hline
\end{tabular}


真と比較して評価する.

円形ダイを用いる場合は, 直径・比重・長さ・質量から 膨張率・収縮率（ダイスウェル）を求めることも可能であ る.また，スパイラルフローのような螺旋状金型に材料を 吐出充填し, 金型内での材料の流動性を直接的に測定する 方法もある.

\section{5 応力緩和}

コンパウンドの応力緩和特性は, プレス成形時の気泡の 噛み込み特性や型形状転写性に影響するといわれている. 特に，近年では射出成形用途で高流動性の配合も多く，プ レスシートの加硫時にエアー抜きが困難な場合もある。応 力緩和の測定には以下の方法がある.

(1)ムーニー粘度計を用いた方法

ムーニー粘度計を用いて応力緩和を求める方法が ISO 289-4 : 2003 「Rubber, unvulcanized - Determination using a shearing-disc viscometer - Part 4: Determination of the Mooney stress-relaxation rate ${ }^{11)}$ 及び ASTM D $1646^{9)}$ に規定されている，眓2に示すように，ムーニー粘 度の測定後にローターを静止させ，そのまま応力／時間の 関係を測定して応力緩和特性を求めるこの方法は, 非常に 短時間で測定が可能である.

さらにムーニー応力緩和に関して, タイヤ用E-SBR 原料ゴムについての報告 ${ }^{12,13)}$ がある. 従来は, 原料ゴム をムーニー粘度で管理していたが, どうしても練り工程で NGとなるロットが発生し，ムーニー粘度との相関が無か った。 そこで，原料ゴム特性を種々の評価手法で比較した 所, ムーニー応力緩和が混練り特性や $\mathrm{CB}$ の取达み時間 BIT (Black Incorporation Time) と良い相関があり, こ れを品質管理項目とすることで, 混練り工程での不具合を 事前に解消出来たという報告である。

ISO 法は, ムーニー值の減少と緩和時間を両対数でプロ ットして，その傾きをMSR（ムーニー応力緩和速度）と して求める. MSRが大きい材料は, 粘性が高く弾性が低 く, 押出し特性が良好であるといえる.

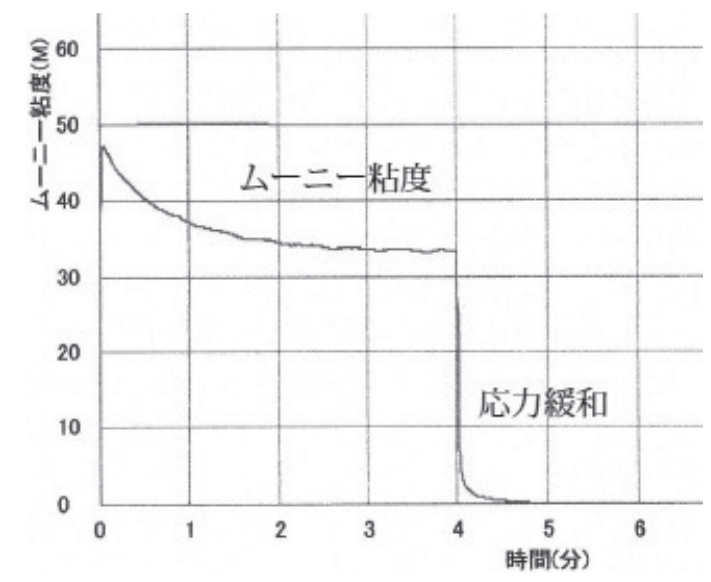

図2 ムーニー応力緩和曲線の一例
ASTM法は，ムーニー粘度からムーニー值が $80 \%$ 低下 した時間を測定する。この方法は，非常に短時間で測定が 可能であり, 一般的には, MSRt80（ムーニー応力の $80 \%$ 緩和時間）と表現される。

(2)加硫度計を用いた方法

ムーニー粘度計と同様の方法で, 最大応力が掛かった状 態で, 加硫度計のローター又はダイを停止させ, 緩和する 応力を測定する，ただし，古いタイプの ODR（Oscillating Disc Rheometer) や平板ダイ式の装置を用いての評価が 多いようである.

(3)回転（ねじり）形レオメータを用いた方法

レオメータには用途に応じた多くの種類が製造されてい る. ASTM D 6049-03 「Standard Test Method for Rubber Property-Measurement of the Viscous and Elastic Behavior of Unvulcanized Raw Rubbers and Rubber Compounds by Compression Between Parallel Plates」 ${ }^{14)}$ には, 応力制御又はひずみ制御が可能な動的粘弾性（回転 ねじり）装置を用いて，液体やエラストマー等の粘弾性特 性のひずみ依存性及び速度依存性が評価可能である。機種 によっては粘度, 応力緩和のみならず, ペイン効果の測定 も可能である.

\section{6 グリーンストレングス}

練り生地のハンドリングや次工程への搬送を行う際の作 業性を評価するために行う, ISO 9026：2007「Raw rubber or unvulcanized compounds-Determination of green strength ${ }^{15)}$, ASTM D 6746-15「Standard Test Method for Determination of Green Strength and Stress Relaxation of Raw Rubber or Unvulcanized Compounds」 ${ }^{16)} に$ 規定されている. 基本的に未加硫生地の引張試験であり, ISO $9026^{15)}$ では, 図3に示す独特の形状にプレス成形した 短冊形試験片を用い, 専用の掴み具で試験を行う.

日本においては分出しした練り生地を JIS 1 号ダンベル 又は短冊形に打抜いて試験に供されるケースが多い.この
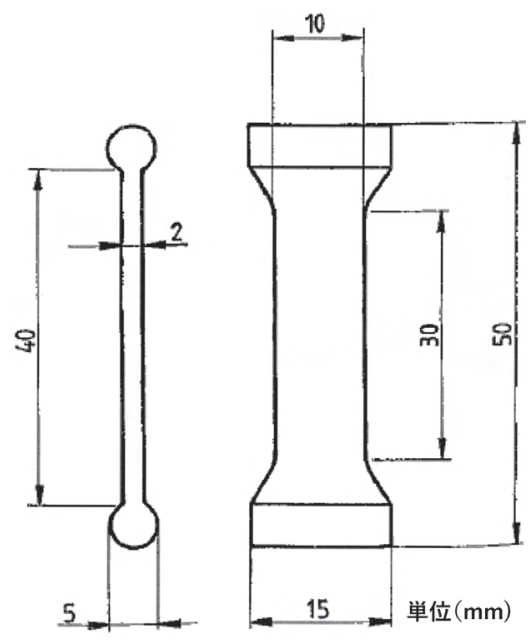

図3 
試験を実施する際は，試験片の掴み方が非常に重要で，同 じコンパウンドでも試験片形状，掴みが変わると，全く異 なった結果となる場合があるので注意が必要である。ま た，この評価方法はJISに規定されていない.

\section{7 ゴム加工特性解析}

比較的新しいゴム加工特性解析装置（例えば, アルフ ア・テクノロジーズInc. 製のRPA2000，（株）東洋精機製 作所製の RLR-4）がある. バイコニカルダイ式の加硫度計 がベースであるが，多くの加工特性評価のアプリケーショ ンを内蔵しており，ひずみ，周波数，温度を広い範囲で可 変可能で, 未加硫〜加硫に至る粘弾性測定, 応力緩和, ペ イン効果, ポリマー中のゲル分率等の解析も可能である.

\section{8 フィラー分散性}

$\mathrm{CB}$ に代表されるフィラー分散の度合いは，ゴムの加工性・ 物性・耐久性に大きく影響を及ぼすので，フィラー分散性の 評価は重要である. CB分散については, ISO 11345：2006 「Rubber - Assessment of carbon black and carbon black/silica dispersion - Rapid comparative methods 2nd edition」 ${ }^{17)}$ やASTM D 2663-14「Standard Test Methods for Carbon Black - Dispersion in Rubber」 ${ }^{18)}$ に規定され ているがJISでは，未だに規格化されていない. 従来は, ミクロトームや透過型電子顕微鏡を用いた評価で，難しい 評価方法であったが，近年では簡便で精度良い測定装置が 上市され有効な評価方法となっている. 詳細は, 別報 ${ }^{19)}$ を参照頂きたい.

\subsubsection{ISOにおける分散性評価方法}

ISO 規格は, ISO 11345 ${ }^{17)}$ があり, CBの種類やシリカ ブレンドに応じて， A 法から E 法が規定されている。いず れもゴム切断面のフィラーが抜けた凹面及びフィラーが残 った凸面に対して 30 度の角度で光を照射し, 垂直面上か ら凹凸面の陰影を観察する。

この表面状態を, A 法から D 法では参照分散度写真と比 較して分散度の評価を行い, E法では大きな凝集塊の数を 計測する。

$\mathrm{A}$ 法及び B 法は $\mathrm{CB}$ 配合を対象とし，C法及び D 法は， $\mathrm{CB}$ 配合又は $\mathrm{CB} /$ シリカ配合を対象とする。この撮影した 写真と参照分散度写真を比較する時に, C法では目視で比 較し, D法では装置内蔵写真と比較して, 分散度のレベル 評価を行う.

E 法は，CB配合を対象とし，倍率×100で顕微鏡写真 を撮影し，画像処理を行うことにより，凝集塊数を計測し 分散度を計算する。

このように多くの手法でフィラー分散度の評価は可能で あるが，詳細はISO $11345^{17)}$ を参照されたい。

\subsubsection{ASTMにおける分散性評価方法}

ASTM D 2663 ${ }^{18)}$ にCB分散性の評価が規定されている. $\mathrm{A}$ 法及び $\mathrm{B}$ 法は通常の顕微鏡や CB 分散計で対応可能で,
ISO 法とほぼ同様であるが，C法及びD 法は専用の装置が 必要であり，日本ではあまり一般的ではない。

\subsubsection{JISにおける分散性評価方法}

ゴム関連の JISには，CB分散性は規定されていない， しかし，プラスチックには, JIS K 6812：2003「ポリオレ フィン管, 継手及びコンパウンドの顔料分散又はカーボン 分散の評価方法」 ${ }^{20)}$ が規定されている.

\section{3. 練り条件を変えたEPDMのCB 分散性と物性}

ゴムの混練り〜加硫工程における成形加工特性の評価 は，上記の方法を用いて行われているが，現場では，この バッチのコンパウンドは良い，このバッチはプレスがやり にくいなどと経験的に判断されるケースも多いと聞く．そ こでコンパウンドの特性がどのように加工性に影響するか を検討するために，異なる練り条件で作製したEPDM / CB配合コンパウンドについて評価を試みた。

\section{1 試料}

試料は, $\mathrm{CB}$ 高充填 EPDM配合とし, 混練り条件の影響 を検討するために, 同一配合について 3 条件で練りを行い, 未加硫コンパウンド及び加硫シートを作製し評価に供し た。

\section{2 実験}

混練りは表 2 の手順で, 以下の 3 種類を行った.

(1)通常ロール練り：カーボンの約半量を入れた後に, 残り のカーボン・オイルを交互に練り込む。（CB練込み時間： 50 分間）

(2)簡略法ロール練り：カーボン・オイル等の配合剤を事前 に混合して，連続的に混練りを行う。（CB練込み時間：15 分間）

(3)バンバリー練り：通常のアップサイドダウン法で混練り を行い, 冷却後, 加硫系をロールにて添加した。（A 練り 所要時間 : 5 分間)

その後, 標準状態で所定時間静置後, 未加硫ゴムの加工 性評価（ムーニー粘度, ムーニー応力緩和, 押出し特性, 加硫特性）を行い，プレス成形した加硫ゴムの評価（CB 分散度, 引張物性）を行った。実験には，ロール練りは, 8インチオープンロールを, バンバリー練りはラボプラス トミル：100C100，B600（株）東洋精機製作所製を，ムー ニー粘度, ムーニー応力緩和は, SMV-300RT : (株) 島津 製作所製を，押出し特性はラボプラストミル：100C100, D2010（株）東洋精機製作所製を，加硫度は, FDR VR-

表2＼cjkstart混練りの手順

\begin{tabular}{|c|c|c|c|}
\hline 手順 & 混練機（1段） & 操作方法 & 混練機（2段） \\
\hline \multirow{2}{*}{ 1段練り } & オープンロール & \multirow{2}{*}{$\begin{array}{l}\text { 加硫系までを連続し } \\
\text { て混練り }\end{array}$} & \multirow[t]{2}{*}{ - } \\
\hline & 密閉式混練機 & & \\
\hline \multirow{2}{*}{ 2段練 } & 密閉式混練機 & \multirow{2}{*}{$\begin{array}{l}\text { 加硫系以外を混練り } \\
\text { L, 取出し泠却後加 } \\
\text { 硫系を混練り }\end{array}$} & オープンロール \\
\hline & 密閉式混練機 & & 密閉式混練機 \\
\hline
\end{tabular}


3110 ：(株）上島製作所製を, CB 分散度は disperGRAD$\mathrm{ER}+$ : アルファ・テクノロジーズInc. 製を, 引張物性は テンソメータ T-2000：アルファ・テクノロジーズInc. 製を 用いた。

\section{3 結果}

$\mathrm{CB}$ の混練りに必要な時間は, (1)通常ロールは, 約 50 分 で，(2)簡略法ロールは約 15 分，(3)バンバリーは，約 5 分と 練り時間に大きな差が生じ, 練りに要したエネルギーが, CB 分散にどのような影響を及ぼすかを，以下の特性で評 価した。

未加硫ゴム物性評価の結果を表 3 に示す。ムーニー粘度 は，混練り時間に依存し(3)バンバリーが高い值を示した。 ムーニー応力緩和は, 練り時間が長いほど緩和時間が早く なり，練込みにより粘性成分が増加したと推定される。押
出し特性は, 押出し速度を変えてガーベイダイ評価を行っ たが, エッジ, 表面光沢等の差はほとんど認められなかっ た，加硫特性について，練り条件の違いによる差はほとん ど認められなかった。

加硫ゴムの物性評価の結果を表 4 に示す。CB分散性は 図 4 に示すように, 練り時間の長い(1)通常ロールがカーボ ン分散度も高く, 平均凝集塊寸法も小さかった。引張強 さ，伸びは，大きな差はないが, (2)簡略ロールについて は，伸びが小さく，CB分散性が影響を及ぼしていると考 えられる。

今回の実験では, $\mathrm{CB}$ 分散度が全体的に良好であったの で諸特性に顕著な差は観察されなかった。しかしながら， 実際の製造現場ではフィラー分散は, 加工工程に大きく影 響するといわれており，的確な評価が求められる。

表3 未加硫ゴムの物性

\begin{tabular}{|l|c|c|c|c|}
\hline \multicolumn{2}{|c|}{ 試料 : 未加硫ゴム } & (1)通常ロール & (2)簡略ロール & (3)バンバリー \\
\hline ムーニー粘度 & $\mathrm{ML} 1+4\left(100^{\circ} \mathrm{C}\right)$ & 33.2 & 34.3 & 39.0 \\
\hline $\mathrm{MSR}$ & - & 0.799 & 0.774 & 0.733 \\
\hline \multirow{3}{*}{ 加硫度 } & $\mathrm{ML}(\mathrm{dNm})$ & 0.98 & 1.01 & 1.04 \\
\cline { 2 - 5 }$\left(160^{\circ} \mathrm{C}\right)$ & $\mathrm{MH}(\mathrm{dNm})$ & 13.2 & 13.2 & 12.7 \\
\cline { 2 - 5 } & $\mathrm{tc10}(\mathrm{min})$ & 1.7 & 1.7 & 1.7 \\
\cline { 2 - 5 } & $\mathrm{tc} 90(\mathrm{~min})$ & 7.9 & 7.9 & 8.0 \\
\hline
\end{tabular}

表4 加硫ゴムの物性

\begin{tabular}{|l|r|c|c|c|}
\hline \multicolumn{2}{|c|}{ 試料：加硫ゴム } & 1)通常ロール & (2)簡略ロール & (3)バンバリー \\
\hline CB 分散度 & $\%$ & 98.2 & 97.7 & 97.7 \\
\hline 平均凝集塊寸法 & $\mu \mathrm{m}$ & 10.7 & 11.4 & 11.1 \\
\hline 引張強さ & $\mathrm{MPa}$ & 12.0 & 11.8 & 12.2 \\
\hline 伸び & $\%$ & 440 & 410 & 440 \\
\hline \multirow{2}{*}{ モジュラス } & $100 \%(\mathrm{MPa})$ & 3.5 & 3.4 & 3.0 \\
\cline { 2 - 5 } & $300 \%(\mathrm{MPa})$ & 9.0 & 8.9 & 8.8 \\
\hline
\end{tabular}

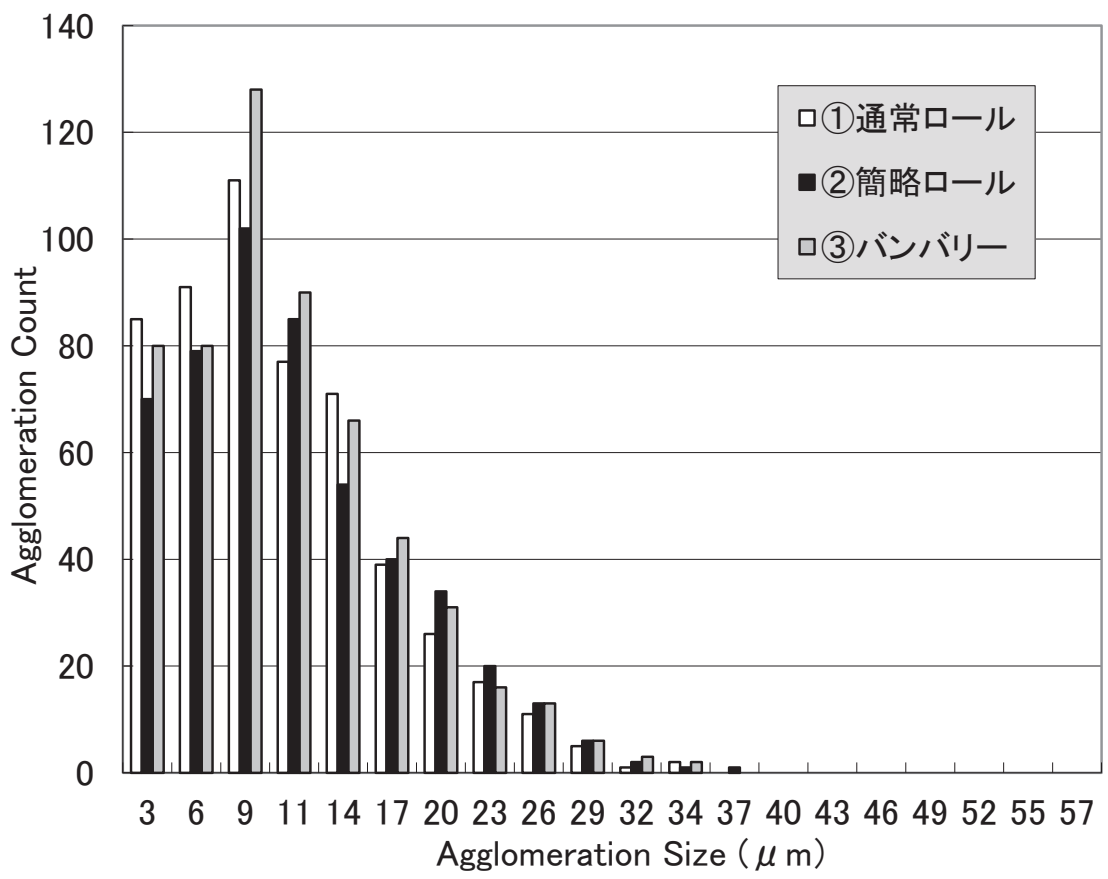

図4 CB 分散性の練り方法の違いによる影響 


\section{4. お わ り に}

フィラー分散の最適化が, ゴム製品の性能を最大限に発 揮するために重要である。五十野ら ${ }^{21)}$ が提唱するCBのフ イラーネットワーク形成は, 優れたゴム物性に寄与してお り, 単純にCBの微分散の効果では無い. この現象は, 乗 用車用タイヤ配合においての適切な $\mathrm{CB}$ 配合量と練り制御 で, 従来から経験的に理解されていたそうである.このよ うに, フィラーの分散度とフィラーネットワークの関係 や, これらと架橋構造との相互関係が, ゴム製品の性能向 上に重要であると考えられる.

ゴムの評価方法は加硫ゴム物性の評価が中心であり，未 加硫ゴムの評価方法は非常に少なく, さらに, 加工性の評 価になるとさらに規格が限られているのが現状である。実 際に業界各社では, 加工性について多種多様な評価がなさ れており，現実的な評価方法を公表いただくことで，ゴム 工業の発展に大きく寄与できると確信している.

\section{References}

1) Lee, B. L.: Rubber Chem. Technol., 52, 1019 (1979)

2) Fujimoto, K.: Nippon Gomu Kyokaishi, 49, 867 (1976)

3 ) Fujimoto, K.; Mifune, N.; Higashi, Y.: Nippon Gomu Kyokaishi, 61, 284 (1988)

4) Ahagon, A.; Miyasaka, K.: Nippon Gomu Kyokaishi, 83, 318 (2010)

5) JIS K 6299 : 2012, Rubber test mixes-Preparation, mixing and vulcanization-Equipment and procedures

6 ) ISO $2393: 2014$, Rubber test mixes-Preparation, mixing and vulcanization-Equipment and procedures

7 ) JIS K 6300-1 : 2013, Rubber, unvulcanized-Physical property-Part 1 : Determination of Mooney viscosity and pre-vulcanization characteristics with Mooney viscometer

8 ) ISO 289-1 : 2015, Rubber, unvulcanized-Determinations using a shearing-disc viscometer-Part 1 : Determination of Mooney viscosity
9 ) ASTM D 1646-07, Standard Test Methods for Rubber-Viscosity, Stress Relaxation, and Pre-Vulcanization Characteristics (Mooney Viscometer)

10) ASTM D 2230-96, Standard Test Method for Rubber Property-Extrudability of Unvulcanized Compounds

11) ISO 289-4 : 2003, Rubber,unvulcanized-Determination using a shearing-disc viscometer-Part 4 : Determination of the Mooney stress-relaxation rate

12) Male, Frank J.: Rubber World, Aug. 73-76 (1994)

13) Male, Frank J.: Rubber World, Nov. 39 (1996)

14) ASTM D 6049-03, Standard Test Method for Rubber Property-Measurement of the Viscous and Elastic Behavior of Unvulcanized Raw Rubbers and Rubber Compounds by Compression Between Parallel Plates

15) ISO $9026: 2007$, Raw rubber or unvulcanized compounds-Determination of green strength

16) ASTM D 6746-15, Standard Test Method for Determination of Green Strength and Stress Relaxation of Raw Rubber or Unvulcanized Compounds

17) ISO $11345: 2006$, Rubber-Assessment of carbon black and carbon black/silica dispersion-Rapid comparative methods 2nd edition

18) ASTM D 2663-14, Standard Test Methods for Carbon Black-Dispersion in Rubber

19) Ontsuka, H.: Nippon Gomu Kyokaishi, 88,380 (2015)

20) JIS K $6812: 2003$, Method for the assessment of the degree of pigment or carbon black dispersion in polyolefin pipes, fittings and compounds

21) Isono, Y.: 156th Gomu Gijyutsu Symposium Yoshishu, 1

(2009)

\section{日本語表記参考文献}

2 ）藤本邦彦：日本ゴム協会誌，49，867（1976）

3 ) 藤本邦彦, 御船 直人, 東良彦:日本ゴム協会誌, 61, 284 (1988)

4 ）阿波根朝浩, 宮坂和夫：日本ゴム協会誌，83，318（2010）

5 ) JIS K 6299：2012，ゴム－試験用試料の作製方法

7 ) JIS K 6300-1：2013, 未加硫ゴム - 物理特性 - 第 1 部 : ムーニー 粘度計による粘度及びスコーチタイムの求め方

19）隠塚裕之：日本ゴム協会誌，88，380（2015）

20) JIS K 6812 : 2003, ポリオレフィン管, 継手及びコンパウンド の顔料分散又はカーボン分散の評価方法

21）五十野善信：第156回ゴム技術シンポジウム，1（2009） 